\title{
THE ROLE OF COMPETITION AND INTRODUCTION EFFORT IN THE SUCCESS OF PASSERIFORM BIRDS INTRODUCED TO NEW ZEALAND
}

\author{
RICHARD P. DUNCAN* \\ Department of Plant Science, P.O. Box 84, Lincoln University, Canterbury, New Zealand
}

Submitted February 5, 1996; Revised June 24, 1996; Accepted July 12, 1996

\begin{abstract}
The finding that passeriform birds introduced to the islands of Hawaii and Saint Helena were more likely to successfully invade when fewer other introduced species were present has been interpreted as strong support for the hypothesis that interspecific competition influences invasion success. I tested whether invasions were more likely to succeed when fewer species were present using the records of passeriform birds introduced to four acclimatization districts in New Zealand. I also tested whether introduction effort, measured as the number of introductions and the total number of birds released, could predict invasion outcomes, a result previously established for all birds introduced to New Zealand. I found patterns consistent with both competition and introduction effort as explanations for invasion success. However, data supporting the two explanations were confounded such that the greater success of invaders arriving when fewer other species were present could have been due to a causal relationship between invasion success and introduction effort. Hence, without data on introduction effort, previous studies may have overestimated the degree to which the number of potential competitors could independently explain invasion outcomes and may therefore have overstated the importance of competition in structuring introduced avian assemblages. Furthermore, I suggest that a second pattern in avian invasion success previously attributed to competition, the morphological overdispersion of successful invaders, could also arise as an artifact of variation in introduction effort.
\end{abstract}

One factor that could prevent new species from successfully invading a community is competition with the resident species. The hypothesis that interspecific competition influences invasion success has been frequently stated (e.g., Elton 1958; Carlquist 1965; Simberloff 1986; Pimm 1989, 1991) but is difficult to test directly because it is hard to determine whether invading and resident species compete and whether it is competition that causes the extinction of failed invaders. Ecologists have therefore sought to test the competition hypothesis indirectly by comparing the outcomes expected if competition dictated which species could successfully invade a community with the patterns found in real communities (Moulton and Pimm 1986a; Pimm 1991). A match between the predicted and actual outcomes provides support for the hypothesis that competitive interactions influence community invasibility.

One prediction of the competition hypothesis is that species-rich communities should be harder to invade than species-poor communities (Elton 1958; Fox and Fox 1986; Moulton 1993). Moulton and colleagues tested this prediction using

*E-mail: duncanr@lincoln.ac.nz. 
the records of birds intentionally introduced to the islands of Hawaii and Saint Helena, and their results supported the competition hypothesis: introduced birds were more likely to invade successfully when fewer other introduced species were present (Moulton and Pimm 1983, 1986a, 1986b; Moulton 1993; Brooke et al. 1995). Moulton and colleagues have used this and other findings consistent with the competition hypothesis (see Results and Discussion) to argue that competition is a major factor influencing invasion success in introduced bird communities (Moulton 1985; Moulton and Pimm 1987; Moulton and Lockwood 1992; Lockwood et al. 1993; Lockwood and Moulton 1994).

In contrast, Veltman et al. (1996) looked at correlates of invasion success in birds introduced to New Zealand and reached a different conclusion. From a suite of variables hypothesized to influence invasion outcomes, they found that introduction effort (measured as either the total number of birds released or the number of separate introductions) was the best predictor of invasion success. Birds introduced more times or in greater numbers were more likely to invade successfully. Similarly, Newsome and Noble (1986) and Witteman and Pimm (data in Pimm 1991) found that birds introduced in greater numbers to Australia and parts of North America had a greater probability of establishing new populations. These findings can explain patterns in avian invasion success without invoking competitive exclusion. The species introduced infrequently or in low numbers had initially small populations and so were more prone to extinction because of stochastic fluctuations in population size (Veltman et al. 1996).

Why have separate studies using similar data reached different conclusions about the factors influencing invasion success in introduced birds? No study has yet tested for patterns consistent with both competition and introduction effort as explanations for invasion success using the data on bird introductions from a single location. It is therefore possible that both competition and introduction effort could influence invasion success, that the effect of either competition or introduction effort or both could vary from place to place, or that a pattern consistent with one explanation could arise as an artifact of the other. In this article, I analyze the records of passeriform bird introductions to four acclimatization districts in New Zealand to assess the role of competition and introduction effort in influencing invasion success. This is possible because the acclimatization societies that carried out the vast majority of avian introductions in New Zealand kept records of the dates, locations, and numbers of birds introduced (e.g., Thomson 1922; Lamb 1964; Wellwood 1968). I use the records from four districts to test whether invasions were more likely to succeed when fewer other species were present, to confirm that passeriform species introduced more often or in greater numbers were more likely to successfully invade, and to investigate whether a pattern consistent with one explanation of invasion success (either competition or introduction effort) could arise as an artifact of the other.

METHODS

\section{Data Collection}

I followed the methods used in previous studies that have used records of bird introductions to test the competition hypothesis so that my results would be 
comparable. Following Moulton and Pimm (1986a, 1987), Lockwood et al. (1993), Moulton (1993), Lockwood and Moulton (1994), and Brooke et al. (1995), I considered only the introduced passeriform birds. I compiled the list of passeriform species introduced to the North and South Islands of New Zealand, including information on the number of introductions, the location of each introduction, and the number of birds released, from Buller (1888), Andersen (1916), Thomson (1922), Westerskov (1953), Lamb (1964), Wellwood (1968), and Williams (1969). The present-day success and distribution of birds were determined from Turbott (1990).

I found 284 recorded introductions of 43 species of passeriform birds to the North and South Islands of New Zealand. All but two introductions occurred between 1861 and 1885. Two hundred forty-four of the introductions $(86 \%)$ were in four acclimatization districts: Auckland, Canterbury, Otago, and Wellington (appendix). I discarded the data on introductions from outside these districts because records from other areas were known to be incomplete (Thomson 1922) or contained too few records for analysis.

The date of introduction to a district was taken as the year of the first recorded release of a species in that district. I used records of the fate of species following introduction (Thomson 1922, 1926) to estimate the year that failed invaders went extinct in each district. When there were no recorded sightings of a failed species following introduction, I assumed that the species went extinct in the second year after the last introduction date. Species that were observed for some years after introduction but subsequently disappeared were assumed to be extinct in the second year following their last recorded observation. Moulton (1985) used the same criteria to estimate extinction dates for failed introductions on the Hawaiian Islands.

Following Moulton and Pimm (1986a), I excluded all introductions of only one bird as these could not have established viable populations. Other studies have excluded introductions of less than some arbitrary "adequate" propagule size, arguing, for example, that introductions of fewer than five birds were unlikely to succeed because of the high chance of stochastic extinction in such small populations (Brooke et al. 1995). I included introductions of at least two birds because recorded instances of successful invasion following the release of only two birds (Drummond 1906) show that two can be an adequate propagule size. When the number of birds liberated at an introduction was not specified but a statement such as "a considerable number" or "several" indicated that at least two birds were released, I included the introduction in the total number of known introductions but could not determine the number of birds released on that occasion. For five species, this meant that the number of birds released in a district was unknown, and those species were dropped from the relevant analyses. I excluded the records of three other introductions: Stagonopleura guttata to the Auckland district (Thomson 1922) because the date of introduction was not recorded, Pycnonotus cafer introduced to Auckland in 1952 but probably exterminated in New Zealand by the Department of Agriculture before 1956 (Turbott 1990), and an Australian shrike introduced to Wellington but not identified to species (Thomson 1922). The final combined data set for the four acclimatization districts included 229 introductions of 42 species. 


\section{Data Analysis}

Following Moulton (1993) and Brooke et al. (1995), I calculated the number of introduced species already present in a district at the time each species was first introduced by ranking species by introduction date. For each species, the number of other species present at the time of first introduction (NSP) was calculated by summing the number of introductions and subtracting the number of extinctions that occurred before the introduction date. If competition influenced invasion success, then successful species should have encountered on average fewer other species at the time of introduction than did failed species (Moulton 1993; Brooke et al. 1995).

A recently introduced bird could only have competed with other species resident in the same acclimatization district at the time of introduction. In calculating NSP and in subsequent analyses, I treated each district independently by assuming that recently introduced birds encountered only those species previously released into the same district and assuming that birds did not spread beyond their district of release to affect the outcome of introductions in other areas. This assumption is reasonable, at least for testing the competition hypothesis, because all but two introductions occurred before 1886 and because observations of the spread of birds following liberation (Thomson 1922, 1926; Guthrie-Smith 1953) suggest that many species would not have spread from their district of release before 1886.

Data from the four acclimatization districts were pooled and analyzed using two-way ANOVA with acclimatization district and invasion outcome (success or failure) as the independent variables. I used three separate ANOVAs to test whether successful and failed species differed significantly in NSP, the number of introductions, and the total number of birds released. In each analysis, I also tested the interaction between invasion outcome and acclimatization district to determine whether any effects of the competitive environment or introduction effort on invasion success differed among districts. The number of introductions and the total number of birds released were log-transformed before analysis to improve normality.

I used multiple-logistic regression to find the combination of variables that best predicted invasion success. The response variable was each species categorized as successful or failed, and the predictor variables were NSP, the number of introductions, the total number of birds released, acclimatization district, and all two-way interaction terms. The best combination of variables was identified using a forward selection procedure in which all variables were tested individually, and the one resulting in the greatest change in residual deviance was included in the model. This procedure was repeated with the remaining variables until the addition of any variable to the model did not result in a significant change in deviance $\left(P<.05\right.$, assessed with a $\chi^{2}$ test $)$.

\section{RESULTS AND DISCUSSION}

Fifteen of the 42 passeriform species introduced to at least one of the four acclimatization districts successfully established in New Zealand. One species 
TABLE 1

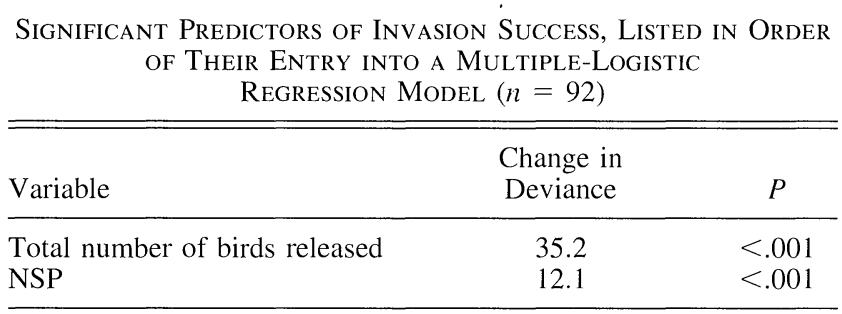

Note.-Also tested for inclusion in the model were the number of introductions, acclimatization district, and all two-way interaction terms. The total number of birds released and number of introductions were $\log$ transformed before analysis.

(Acridotheres tristis) failed to establish in three districts to which it was introduced but did succeed in Auckland, where there were no records of its intentional introduction.

\section{Competition and Introduction Effort}

The data were consistent with the competition hypothesis: successful invaders faced significantly fewer species on average at the time of introduction (mean $=$ $5.9, n=48$ ) than did failed species (mean $=11.8, n=49$, two-way ANOVA $F=32.6, P<.001)$. The data were also consistent with introduction effort as an explanation for invasion success. The successful species were introduced significantly more often (mean $=3.3, n=48$ ) than were the failed species (mean $=1.5, n=49$, two-way ANOVA $F=47.8, P<.001$ ), and successful species were introduced in greater numbers (mean $=135, n=48$ ) than were the failed species (mean $=31, n=44$, two-way ANOVA $F=48.1, P<.001$ ). Furthermore, none of the interactions between invasion outcome and district of introduction were significant $(P>.1)$, which suggests that any influence of the competitive environment or introduction effort on invasion success was not affected by geographical location.

However, the result consistent with the competition hypothesis was confounded with variation in introduction effort. The species first introduced when fewer other species were present were also introduced more often and in greater numbers (Spearman rank correlation of NSP with the number of introductions was $-0.47, n=97, P<.001$, and of NSP with the total number of birds released was $-0.39, n=92, P<.001)$. The results were therefore equivocal: either the competitive environment or introduction effort or both could have influenced invasion success, and because of their high degree of correlation, it may be difficult to distinguish statistically the effect of one from the other. However, both independently explained some of the variation in invasion success. The total number of birds released was the best predictor in the logistic regression model, but, having accounted for variation due to introduction effort, NSP still explained significant additional variation (table 1). This suggests that both introduction effort and the number of potential competitors could have in- 
TABLE 2

\begin{tabular}{|c|c|}
\hline $\begin{array}{l}\text { SPEARMAN RANK CORRELATIONS BETWE } \\
\text { OF BREEDING BIRDS IN BRITAIN AND I } \\
\text { INTRODUCTION EFFORT, DATE O } \\
\text { INTRODUCTION, AND NSP }(n=\end{array}$ & $\begin{array}{l}\text { HE NUMBER } \\
\text { SURES OF } \\
\text { RST } \\
\text { ) }\end{array}$ \\
\hline Measure & Correlation \\
\hline $\begin{array}{l}\text { Number of acclimatization districts } \\
\text { Mean number of introductions per district } \\
\text { Mean number of birds released per district } \\
\text { Mean date of first introduction } \\
\text { Mean NSP }\end{array}$ & $\begin{aligned} & .48^{*} \\
& .60^{* *} \\
& .56^{* *} \\
&-.49^{*} \\
&-.54 * *\end{aligned}$ \\
\hline
\end{tabular}

NoTE.-The number of acclimatization districts is the number of districts to which a species was introduced. Here, NSP is the number of other introduced species present in a district at the time of introduction.

$* P<.05$.

$* * P<.01$.

fluenced invasion outcomes in New Zealand. Nonetheless, a measure of introduction effort was the best predictor, and the addition of NSP to the regression model when the number of birds released was already a predictor (table 1) halved the change in deviance compared with when NSP was included alone (logistic regression with NSP as the only predictor in the model, change in deviance $=25.6, n=92, P<.001)$. Thus, in the absence of data on introduction effort, we might have seriously overestimated the likely contribution of the number of potential competitors to explaining invasion outcomes.

Why would measures of introduction effort be confounded with the number of species present at the time of introduction? Two factors are likely to have influenced introduction effort: the desirability of a species for introduction and its availability in Britain, from where most birds introduced to New Zealand were imported. It is plausible that the readily available or more desired species were introduced first by the acclimatization societies (arriving when fewer other species were present) and were also introduced more often and in greater numbers, potentially generating a spurious correlation between invasion success and NSP if the birds repeatedly introduced had more chance of success. If this explanation is correct, then measures of species desirability or availability should be positively correlated with introduction effort and negatively correlated with the year of first introduction and consequently with NSP.

I tested these predictions by estimating both the availability and the desirability of the 25 species introduced to New Zealand from Britain (appendix). As a measure of availability in Britain, I used the estimated number of breeding birds in Britain and Ireland from Sharrock (1976). When the number of birds was given as a range, I used the arithmetic mean. Compared with species with small British populations, species with large British populations were introduced to more districts in New Zealand and were introduced more often and in greater numbers within those districts (table 2). In addition, species with large British 
populations were introduced significantly earlier into districts and therefore encountered fewer potential competitors than were species with small British populations, consistent with expectations.

I identified as desirable the passeriform species in two lists reproduced in Thomson (1922) advertising birds wanted for introduction to Auckland and Canterbury in 1864. All of the species on the lists were British birds. Of the 25 passeriforms introduced to New Zealand from Britain, the eight on Thomson's list were introduced to significantly more districts and were introduced more often and in greater numbers within those districts (Kruskal-Wallis $\chi^{2}=6.6,5.9$, and 3.8, respectively; all $P^{\prime}$ 's $\left.<.05\right)$. This pattern was even more pronounced when non-British birds were included in the analysis. The desired species were also introduced earlier to districts than were other species, though not significantly so (Kruskal-Wallis $\chi^{2}=2.6, P=.11$ ), and encountered fewer potential competitors $\left(\chi^{2}=4.7, P=.03\right)$.

All of these results are consistent with the following scenario: a critical determinant of invasion success in passeriform birds introduced to New Zealand was introduction effort. Greater effort was made to introduce a group of desirable or readily available (mostly British) species that consequently succeeded in invading. These species were also introduced to acclimatization districts early on because of their desirability or availability, which explains in part why successful invaders tended to encounter fewer other introduced species at the time of their first introduction.

In Hawaii and Saint Helena, the finding that introduced passeriform birds were more likely to invade successfully when fewer other introduced species were present was interpreted as strong support for the hypothesis that interspecific competition influences invasion success (Moulton and Pimm 1986a; Moulton 1993; Brooke et al. 1995). The results of the present study show that this pattern could arise wholly or partly as an artifact of a causal relationship between invasion success and introduction effort, providing an alternative to competition to explain why invasion success rates are higher when fewer other species are present. The New Zealand results suggest that previous studies may have overstated the importance of competition and that data on introduction effort are needed to clarify the degree to which the number of potential competitors can independently explain patterns in avian invasion success in other areas.

\section{Accounting for a Second Pattern Consistent with Competition}

Moulton and colleagues have repeatedly found a second pattern in the success or failure of bird introductions consistent with the outcome of competition. On the islands of Oahu (Hawaii), Tahiti, and Bermuda the successful invaders tend to be morphologically overdispersed, meaning they overlap less in their morphological characteristics than would be expected if the successors were chosen randomly from a larger pool of introduced birds (Moulton and Pimm 1987; Moulton and Lockwood 1992; Lockwood et al. 1993; Lockwood and Moulton 1994). Hence, even if we discard competition as the explanation for the greater success of birds introduced when fewer other species were present, we repeatedly find a 
pattern of morphological overdispersion consistent with the competition hypothesis. However, morphological overdispersion in successful species could also arise as a spurious consequence of variation in introduction effort if attempts were made to introduce species that were morphologically different from one another. Acclimatization societies, for example, may have put greater effort into introducing one or a few species that were representative of each of several morphological types rather than concentrating on introducing several species of the same type. This is certainly plausible in New Zealand, where the desired species were selected to fill a range of perceived vacant niches (Druett 1983). Even on islands without societies to oversee introductions, the same pattern of morphological overdispersion could arise if individuals put greater effort into introducing species that differed from those that had already successfully established.

\section{The All-or-None Success Pattern}

The data for passeriform introductions to the four acclimatization districts in New Zealand show a second striking pattern: species either succeeded or failed everywhere they were introduced. Of the 29 species introduced to two or more districts, 13 succeeded in all districts to which they were intentionally introduced, and 14 failed in all districts, although A. tristis succeeded in a district outside its recorded introduction. Only one species showed a mixed result: Corvus frugilegus successfully established a population in Canterbury but failed to establish in Auckland. Simberloff and Boecklen (1991) found a similar all-ornone invasion pattern among birds introduced to the Hawaiian islands and hypothesized that it was an outcome of intrinsic differences in species' invasive abilities. Some species had characteristics that made them good invaders, so they succeeded almost everywhere they were introduced, whereas other species were inherently poor invaders and so repeatedly failed. Hence, the all-or-none pattern in the New Zealand data suggests that particular characteristics of the introduced species may have influenced invasion outcomes.

However, closer examination of the data suggests that the all-or-none pattern is a consequence of variation in introduction effort. The species that succeeded everywhere were introduced to significantly more districts (median $=4, n=$ 13) than were the failed species (median $=2, n=14$, Kruskal-Wallis $\chi^{2}=$ $11.2, P<.001$; see also Veltman et al. 1996), successful species had more introductions per district $($ median $=3.7)$ than did failed species $($ median $=1.5$, Kruskal-Wallis $\chi^{2}=11.0, P<.001$ ), and successful species were introduced in greater numbers per district $($ median $=154)$ than were failed species (median $=$ 20, Kruskal-Wallis $\chi^{2}=11.4, P<.001$ ). Thus, the species that succeeded everywhere appeared to do so because they were consistently introduced more often and in greater numbers. For example, the two species that failed despite being introduced to all four acclimatization districts (Erithacus rubecula and Carduelis cannabina) were introduced in significantly fewer numbers (median $=36$ birds per district) than the nine species that succeeded in all four districts (median $=154$ birds per district, Kruskal-Wallis $\chi^{2}=4.5, P=.034$ ). One species proved a notable exception: Emberiza cirlus succeeded in the two districts 
where it was intentionally released despite only two introductions totaling 11 birds.

Moulton and Pimm (1983) and Simberloff and Boecklen (1991) suggested another way of testing the hypothesis that invasion success is governed by characteristics of the species being introduced. If species are inherently good or bad invaders, then those species that succeeded in New Zealand should also have succeeded when introduced to locations outside New Zealand, while those species that failed in New Zealand should have consistently failed when introduced elsewhere. Following Moulton and Pimm (1983), Simberloff and Boecklen (1991), and Brooke et al. (1995), I calculated the rate of introduction success outside New Zealand from the data in Long (1981) for the 30 species listed in the appendix that were also introduced to other locations. The species that failed to invade in New Zealand did not differ significantly in their success rate when introduced elsewhere (median $=0.0, n=19$ ) compared with the species that succeeded in New Zealand (median $=0.6, n=11$, Kruskal-Wallis $\chi^{2}=0.18$, $P=.7$ ). This result does not support the hypothesis that successful and failed species were inherently different in their invasive abilities.

I have shown that population size in Britain correlated with introduction effort in New Zealand (table 2) and that introduction effort in turn correlated with invasion success. I have argued that the explanation for these correlations is that the more abundant species in Britain were selected for introduction or were more readily available for capture and export and so were introduced to New Zealand in greater numbers and were therefore more successful in invading. However, it is also possible that the species with large British populations were particularly good invaders because the characteristics that led to the species being abundant in Britain might also enhance invasion success elsewhere. This interpretation was not supported by the data, because population size in Britain was not a significant predictor of invasion success in New Zealand (logistic regression, $n=25, \chi^{2}=2.9, P=.09$ ).

Finally, Veltman et al. (1996) have comprehensively searched for life-history characteristics that could explain invasion success in introduced New Zealand birds. They found that migratory tendency was the only life-history attribute that significantly correlated with invasion success, after controlling for differences in introduction effort. Moreover, migration explained much less of the variation than measures of introduction effort, which suggests again that in New Zealand introduction effort was the most important determinant of invasion outcomes.

\section{CONCLUSION}

The New Zealand data on passeriform introductions confirm a general finding that introduction effort is a crucial factor determining the success or failure of bird introductions (Newsome and Noble 1986; Pimm 1991; Veltman et al. 1996). This finding alone has important implications for understanding the structure of introduced avian assemblages because it suggests that communities of introduced birds may be largely composed of those species that happened to arrive 
in an area in sufficient numbers to colonize successfully. However, the New Zealand data also show that unexpected and often striking patterns in avian invasion success, consistent with explanations such as competition, can emerge as a consequence of variation in introduction effort affecting the success or failure of introductions. In the absence of data on introduction effort, the New Zealand results caution against attributing such striking patterns entirely to causes such as competition.

\section{ACKNOWLEDGMENTS}

I thank C. M. Frampton for statistical advice and M. P. Moulton, R. E. Ricklefs, M. Sanders, C. J. Veltman, S. D. Wratten, and an anonymous reviewer for helpful comments on earlier versions of the manuscript.

\section{APPENDIX}

TABLE A1

The Passeriform Birds Introduced to Four Acclimatization Districts in New Zealand, Listed by District and IN ORder OF THE YeAR OF FIRST INTRODUCTION

\begin{tabular}{|c|c|c|c|c|c|c|}
\hline Species & $\begin{array}{c}\text { Year of } \\
\text { Introduction }\end{array}$ & $\begin{array}{l}\text { Year of } \\
\text { Extinction }\end{array}$ & NSP & $\begin{array}{l}\text { Number of } \\
\text { Introductions }\end{array}$ & $\begin{array}{l}\text { Total } \\
\text { Number } \\
\text { of Birds } \\
\text { Released }\end{array}$ & $\begin{array}{c}\text { Number of } \\
\text { Breeding } \\
\text { Birds in } \\
\text { Britain } \\
\left(\times 10^{3}\right)\end{array}$ \\
\hline \multicolumn{7}{|l|}{ Auckland: } \\
\hline Gymnorhina tibicen & 1861 & $\cdots$ & 0 & 2 & 10 & $\ldots$ \\
\hline Fringilla coelebs & 1864 & $\cdots$ & 1 & 4 & 113 & 7,000 \\
\hline Sturnus vulgaris & 1865 & $\ldots$ & 2 & 3 & 109 & 5,500 \\
\hline Turdus merula & 1865 & $\cdots$ & 2 & 4 & 170 & 7,000 \\
\hline Carduelis chloris & 1865 & $\cdots$ & 2 & 3 & 51 & 1,500 \\
\hline Passer domesticus & 1865 & $\cdots$ & 2 & 2 & 49 & 5,300 \\
\hline Emberiza citrinella & 1865 & $\ldots$ & 2 & 6 & 345 & 1,000 \\
\hline Carduelis cannabina & 1865 & 1876 & 2 & 4 & 42 & 1,200 \\
\hline Alauda arvensis & 1867 & $\cdots$ & 8 & 2 & 62 & 3,000 \\
\hline Carduelis carduelis & 1867 & $\cdots$ & 8 & 2 & 55 & 300 \\
\hline Turdus philomelos & 1867 & $\ldots$ & 8 & 2 & 125 & 7,000 \\
\hline Padda oryzivora & 1867 & 1869 & 8 & 1 & 6 & $\ldots$ \\
\hline Lonchura castaneothorax & 1867 & 1873 & 8 & 2 & 27 & $\ldots$ \\
\hline Prunella modularis & 1868 & $\ldots$ & 13 & 4 & 46 & 5,300 \\
\hline Sylvia communis & 1868 & 1870 & 13 & 1 & 2 & 600 \\
\hline Lonchura punctulata & 1868 & 1870 & 13 & 1 & 8 & $\ldots$ \\
\hline Piranga rubra & 1868 & 1871 & 13 & 1 & 2 & $\cdots$ \\
\hline Passer montanus & 1868 & 1873 & 13 & 2 & 12 & 250 \\
\hline Neochmia temporalis & 1868 & 1873 & 13 & 2 & 12 & $\ldots$ \\
\hline Erithacus rubecula & 1868 & 1874 & 13 & 3 & 9 & 5,000 \\
\hline Agelaius phoeniceus & 1869 & 1871 & 19 & 1 & 2 & $\ldots$ \\
\hline Sturnella neglecta & 1869 & 1871 & 19 & 1 & 2 & $\ldots$ \\
\hline Corvus frugilegus & 1869 & 1905 & 19 & 2 & 66 & 3,000 \\
\hline Stagonopleura bella & 1870 & 1872 & 20 & 1 & 2 & $\ldots$ \\
\hline Carduelis flammea & 1872 & $\ldots$ & 17 & 1 & 209 & 300 \\
\hline Sylvia atricapilla & 1872 & 1874 & 17 & 1 & 5 & 200 \\
\hline Lullula arborea & 1872 & 1874 & 17 & 1 & 5 & .65 \\
\hline Malurus cyaneus & 1923 & 1925 & 12 & 1 & 12 & $\ldots$ \\
\hline
\end{tabular}


TABLE A1 (Continued)

\begin{tabular}{|c|c|c|c|c|c|c|}
\hline Species & $\begin{array}{c}\text { Year of } \\
\text { Introduction }\end{array}$ & $\begin{array}{l}\text { Year of } \\
\text { Extinction }\end{array}$ & NSP & $\begin{array}{l}\text { Number of } \\
\text { Introductions }\end{array}$ & $\begin{array}{c}\text { Total } \\
\text { Number } \\
\text { of Birds } \\
\text { Released }\end{array}$ & $\begin{array}{l}\text { Number of } \\
\text { Breeding } \\
\text { Birds in } \\
\text { Britain } \\
\left(\times 10^{3}\right)\end{array}$ \\
\hline \multicolumn{7}{|l|}{ Canterbury: } \\
\hline T. merula & 1861 & $\cdots$ & 0 & 7 & 477 & 7,000 \\
\hline C. frugilegus & 1862 & $\ldots$ & 1 & 4 & 36 & 3,000 \\
\hline A. arvensis & 1863 & $\ldots$ & 2 & 5 & 434 & 3,000 \\
\hline C. chloris & 1863 & $\ldots$ & 2 & 2 & 32 & 1,500 \\
\hline T. philomelos & 1863 & $\cdots$ & 2 & 7 & 299 & 7,000 \\
\hline G. tibicen & 1864 & $\ldots$ & 5 & 9 & 313 & $\ldots$ \\
\hline L. castaneothorax & 1864 & 1866 & 5 & 1 & 12 & $\cdots$ \\
\hline Stagonopleura guttata & 1864 & 1868 & 5 & 1 & $\ldots$ & $\ldots$ \\
\hline F. coelebs & 1865 & $\ldots$ & 8 & 4 & 16 & 7,000 \\
\hline C. carduelis & 1865 & $\ldots$ & 8 & 4 & 265 & 300 \\
\hline S. vulgaris & 1867 & $\ldots$ & 9 & 4 & 125 & 5,500 \\
\hline C. cannabina & 1867 & 1928 & 9 & 4 & 119 & 1,200 \\
\hline C. flammea & 1868 & $\ldots$ & 10 & 5 & 326 & 300 \\
\hline P. modularis & 1868 & $\cdots$ & 10 & 6 & 210 & 5,300 \\
\hline P. domesticus & 1868 & $\ldots$ & 10 & 1 & 44 & 5,300 \\
\hline Fringilla montifringilla & 1868 & 1882 & 10 & 4 & 117 & $\ldots$ \\
\hline Acridotheres tristis & 1871 & 1901 & 14 & 1 & 18 & $\cdots$ \\
\hline Corvus monedula & 1872 & 1874 & 15 & 1 & 5 & 1,000 \\
\hline E. citrinella & 1873 & $\ldots$ & 16 & 3 & 236 & 1,000 \\
\hline Emberiza schoeniclus & 1873 & 1882 & 16 & 2 & 7 & 600 \\
\hline Parus caeruleus & 1874 & 1876 & 17 & 1 & $\ldots$ & 10,000 \\
\hline Pyrrhula pyrrhula & 1875 & 1877 & 18 & 1 & 2 & 600 \\
\hline E. rubecula & 1879 & 1881 & 17 & 1 & $\ldots$ & 5,000 \\
\hline Manorina melanocephala & 1879 & 1881 & 17 & 1 & 200 & $\ldots$ \\
\hline Carduelis spinus & 1879 & 1882 & 17 & 2 & 52 & 30 \\
\hline Carduelis flavirostris & 1880 & 1882 & 20 & 1 & 21 & 30 \\
\hline \multicolumn{7}{|l|}{ Otago: } \\
\hline G. tibicen & 1865 & $\cdots$ & 0 & 5 & 81 & $\ldots$ \\
\hline T. merula & 1865 & $\ldots$ & 0 & 5 & 138 & 7,000 \\
\hline T. philomelos & 1865 & $\cdots$ & 0 & 5 & 145 & 7,000 \\
\hline S. vulgaris & 1867 & $\cdots$ & 3 & 3 & 169 & 5,500 \\
\hline A. arvensis & 1867 & $\ldots$ & 3 & 3 & 100 & 3,000 \\
\hline C. carduelis & 1867 & $\ldots$ & 3 & 4 & 118 & 300 \\
\hline C. monedula & 1867 & 1869 & 3 & 1 & $\cdots$ & 1,000 \\
\hline N. temporalis & 1867 & 1869 & 3 & 1 & 4 & $\ldots$ \\
\hline C. cannabina & 1867 & 1870 & 3 & 2 & 20 & 1,200 \\
\hline F. coelebs & 1868 & $\ldots$ & 9 & 3 & 99 & 7,000 \\
\hline C. flammea & 1868 & $\ldots$ & 9 & 2 & 81 & 300 \\
\hline C. chloris & 1868 & $\ldots$ & 9 & 1 & 8 & 1,500 \\
\hline P. modularis & 1868 & $\cdots$ & 9 & 2 & 98 & 5,300 \\
\hline P. domesticus & 1868 & $\ldots$ & 9 & 2 & 14 & 5,300 \\
\hline E. citrinella & 1868 & $\ldots$ & 9 & 2 & 39 & 1,000 \\
\hline P. montanus & 1868 & 1870 & 9 & 1 & 2 & 250 \\
\hline Emberiza cirlus & 1871 & $\ldots$ & 12 & 1 & 7 & .53 \\
\hline E. schoeniclus & 1871 & 1873 & 12 & 1 & 4 & 600 \\
\hline C. flavirostris & 1871 & 1873 & 12 & 1 & 38 & 30 \\
\hline A. tristis & 1874 & 1890 & 13 & 1 & $\cdots$ & $\ldots$ \\
\hline E. rubecula & 1879 & 1893 & 14 & 3 & 62 & 5,000 \\
\hline M. melanocephala & 1880 & 1884 & 15 & 1 & 80 & $\ldots$ \\
\hline
\end{tabular}


TABLE A1 (Continued)

\begin{tabular}{|c|c|c|c|c|c|c|}
\hline Species & $\begin{array}{c}\text { Year of } \\
\text { Introduction }\end{array}$ & $\begin{array}{c}\text { Year of } \\
\text { Extinction }\end{array}$ & NSP & $\begin{array}{l}\text { Number of } \\
\text { Introductions }\end{array}$ & $\begin{array}{c}\text { Total } \\
\text { Number } \\
\text { of Birds } \\
\text { Released }\end{array}$ & $\begin{array}{c}\text { Number of } \\
\text { Breeding } \\
\text { Birds in } \\
\text { Britain } \\
\left(\times 10^{3}\right)\end{array}$ \\
\hline \multicolumn{7}{|l|}{ Wellington: } \\
\hline P. domesticus & 1866 & $\ldots$ & 0 & 1 & 200 & 5,300 \\
\hline G. tibicen & 1874 & $\cdots$ & 1 & 1 & 260 & $\ldots$ \\
\hline F. coelebs & 1874 & $\cdots$ & 1 & 4 & 126 & 7,000 \\
\hline A. arvensis & 1874 & $\ldots$ & 1 & 2 & 108 & 3,000 \\
\hline Manorina melanophrys & 1874 & 1876 & 1 & 1 & 2 & $\ldots$ \\
\hline S. guttata & 1874 & 1876 & 1 & 1 & 12 & $\cdots$ \\
\hline M. melanocephala & 1874 & 1880 & 1 & 4 & 224 & $\cdots$ \\
\hline F. montifringilla & 1874 & 1887 & 1 & 1 & 3 & $\cdots$ \\
\hline C. flammea & 1875 & $\ldots$ & 8 & 1 & 2 & 300 \\
\hline A. tristis & 1875 & 1920 & 8 & 2 & 70 & $\ldots$ \\
\hline C. spinus & 1876 & 1921 & 8 & 1 & 2 & 30 \\
\hline S. vulgaris & 1877 & $\cdots$ & 9 & 5 & 298 & 5,500 \\
\hline T. philomelos & 1878 & $\ldots$ & 10 & 1 & 8 & 7,000 \\
\hline E. cirlus & 1880 & $\ldots$ & 10 & 1 & 4 & .53 \\
\hline C. carduelis & 1880 & $\cdots$ & 10 & 3 & 177 & 300 \\
\hline P. modularis & 1880 & $\ldots$ & 10 & 3 & 50 & 5,300 \\
\hline C. cannabina & 1881 & 1928 & 13 & 1 & 22 & 1,200 \\
\hline E. rubecula & 1883 & 1888 & 14 & 1 & 10 & 5,000 \\
\hline S. bella & 1884 & 1886 & 15 & 1 & 8 & $\ldots$ \\
\hline Poephila guttata & 1884 & 1886 & 15 & 1 & 12 & $\cdots$ \\
\hline Emberiza hortulana & 1885 & 1888 & 17 & 1 & 6 & $\cdots$ \\
\hline
\end{tabular}

Note. - Two hundred Passer domesticus introduced at Wanganui in 1866 (Buller 1888) were included in the Wellington district, and 12 Malurus cyaneus introduced at Rotorua in 1923 (Westerskov 1953) were included in the Auckland district. Nomenclature follows Sibley and Monroe (1990).

\section{LITERATURE CITED}

Andersen, J. C. 1916. Jubilee history of South Canterbury. Whitcomb \& Tombs, Auckland.

Brooke, R. K., J. L. Lockwood, and M. P. Moulton. 1995. Patterns of success in passeriform bird introductions on Saint Helena. Oecologia (Berlin) 103:337-342.

Buller, W. L. 1888. A history of the birds of New Zealand. 2d ed. London.

Carlquist, S. 1965. Island life. Natural History Press, New York.

Druett, J. 1983. Exotic intruders. Heinemann, Auckland.

Drummond, J. 1906. On introduced birds. Transactions of the New Zealand Institute 39:227-252.

Elton, C. S. 1958. The ecology of invasions by animals and plants. Chapman \& Hall, London.

Fox, M. D., and B. J. Fox. 1986. The susceptibility of natural communities to invasion. Pages 57-66 in R. H. Groves and J. J. Burdon, eds. Ecology of biological invasions. Cambridge University Press, Cambridge.

Guthrie-Smith, H. 1953. Tutira: the story of a New Zealand sheep station. Blackwood, London.

Lamb, R. C. 1964. Birds, beasts and fishes. Caxton, Christchurch.

Lockwood, J. L., and M. P. Moulton. 1994. Ecomorphological pattern in Bermuda birds: the influence of competition and implications for nature preserves. Evolutionary Ecology 8:53-60.

Lockwood, J. L., M. P. Moulton, and S. K. Anderson. 1993. Morphological assortment and the assembly of communities of introduced passeriforms on oceanic islands: Tahiti versus Oahu. American Naturalist 141:398-408.

Long, J. L. 1981. Introduced birds of the world. Universe, New York.

Moulton, M. P. 1985. Morphological similarity and coexistence of congeners: an experimental test with introduced Hawaiian birds. Oikos 44:301-305. 
1993. The all-or-none pattern in introduced Hawaiian passerines: the role of competition sustained. American Naturalist 141:301-305.

Moulton, M. P., and J. L. Lockwood. 1992. Morphological dispersion of introduced Hawaiian finches: evidence for competition and a Narcissus effect. Evolutionary Ecology 6:45-55.

Moulton, M. P., and S. L. Pimm. 1983. The introduced Hawaiian avifauna: biogeographical evidence for competition. American Naturalist 121:669-690.

1986a. The extent of competition in shaping an introduced avifauna. Pages 80-97 in J. Diamond and T. J. Case, eds. Community ecology. Harper \& Row, New York.

1986b. Species introductions to Hawaii. Pages 231-249 in H. A. Mooney and J. A. Drake, eds. Ecology of biological invasions of North America and Hawaii. Springer, Berlin.

1987. Morphological assortment in introduced Hawaiian passerines. Evolutionary Ecology 1: 113-124.

Newsome, A. E., and I. R. Noble. 1986. Ecological and physiological characters of invading species. Pages 1-20 in R. H. Groves and J. J. Burdon, eds. Ecology of biological invasions. Cambridge University Press, Cambridge.

Pimm, S. L. 1989. Theories of predicting success and impact of introduced species. Pages 351-367 in J. A. Drake, H. A. Mooney, F. di Castri, R. H. Groves, F. J. Kruger, M. Rejmánek, and M. Williamson, eds. Biological invasions: a global perspective. Wiley, Chichester.

1991. The balance of nature? University of Chicago Press, Chicago.

Sharrock, J. T. R. 1976. The atlas of breeding birds in Britain and Ireland. British Trust for Ornithology, Tring.

Sibley, C. G., and B. L. Monroe. 1990. Distribution and taxonomy of birds of the world. Yale University Press, New Haven, Conn.

Simberloff, D. 1986. Introduced insects: a biogeographic and systematic perspective. Pages 3-26 in H. A. Mooney and J. A. Drake, eds. Ecology of biological invasions of North America and Hawaii. Springer, Berlin.

Simberloff, D., and W. Boecklen. 1991. Patterns of extinction in the introduced Hawaiian avifauna: a reexamination of the role of competition. American Naturalist 138:300-327.

Thomson, G. M. 1922. The naturalisation of animals and plants in New Zealand. Cambridge University Press, Cambridge.

- 1926. Wild life in New Zealand. II. Introduced birds and fishes. Government Printer, Wellington.

Turbott, E. G. 1990. Checklist of the birds of New Zealand and the Ross Dependency, Antarctica. Random Century, Auckland.

Veltman, C. J., S. Nee, and M. J. Crawley. 1996. Correlates of introduction success in exotic New Zealand birds. American Naturalist 147:542-557.

Wellwood, J. M. 1968. Hawke's Bay Acclimatization Society centenary 1868-1968. Hawke's Bay Acclimatization Society, Hastings.

Westerskov, K. E. 1953. Introduction into New Zealand of the Australian blue wren in 1923. Notornis 5:106-107.

Williams, G. R. 1969. Introduced birds. Pages 435-451 in G. A. Knox, ed. The natural history of Canterbury. Reed, Wellington. 